Food Control

August 2016, Volume 66 Pages 158-165

http://dx.doi.org/10.1016/i.foodcont.2016.02.003

http://archimer.ifremer.fr/doc/00313/42396/

(c) 2016 Elsevier Ltd. All rights reserved

\title{
Stakeholders' perceptions, attitudes and practices towards risk prevention in the food chain
}

\author{
Lupo Coralie ${ }^{1,{ }^{*}}$, Wilmart O. ${ }^{2}$, Van Huffel X. ${ }^{2}$, Dal Pozzo F. ${ }^{3}$, Saegerman C. ${ }^{3,4}$
}

${ }^{1}$ IFREMER, RBE-SG2M-LGPMM, Station La Tremblade, Avenue de Mus de loup, 17390-La

Tremblade, France

${ }^{2}$ Staff Direction for Risk Assessment, Directorate-general of Control Policy, Federal Agency for the Safety of the Food Chain (FASFC), Brussels, Belgium

${ }^{3}$ Research Unit in Epidemiology and Risk Analysis Applied to Veterinary Science (UREARULg), Fundamental and Applied Research for Animals \& Health (FARAH), Faculty of Veterinary Medicine, University of Liege, Liege, Belgium

${ }^{4}$ Belgium Scientific Committee of the Federal Agency for the Safety of the Food Chain (FASFC), Brussels, Belgium

* Corresponding author : Coralie Lupo, email address : clupo@ifremer.fr

\begin{abstract}
:
An online survey was conducted to describe stakeholders' perceptions, attitudes and practices towards risk prevention in the food chain and to explore if common features could be extracted from different fields of competency or groups of stakeholders. Out of 80 participants, $60 \%$ believed that pathogenic microorganisms were the main hazard to prevent. Twenty-four percent perceived climate change as the main risk factor. Seventy-three percent believed that hazards in the food chain are preventable and they often showed a positive attitude towards risk prevention measures. The opinion of $75 \%$ of stakeholders was that prevention measures should be compulsory and under the shared responsibility of both food business operators and competent authority. Seventy-five percent of the respondents had recent experience with particular hazards and declared to have undertaken risk reduction measures. Incentives to implement measures were policy obligation and public health consequences whereas barriers were budgetary reasons and doubts about their effectiveness. However, there was not always a complete agreement between the perceived usefulness of risk prevention measures and their effective implementation, and conversely. No significant difference could be observed in the perceptions, attitudes and practices towards risk prevention between neither groups of stakeholders nor their fields of competency. The results are important for improving the risk communication process because the same issues can be emphasized when promoting risk prevention in the food chain regardless of the type of food sectors and the groups of stakeholders.
\end{abstract}




\section{Highlights}

- Stakeholders' perceptions, attitudes and practices towards risk prevention in the food chain were described. Pathogenic microorganisms were perceived as the main hazard. A positive attitude towards risk prevention was observed. Attitude and behaviour towards risk prevention were not always consistent. Results were homogeneous between stakeholder groups and their fields of competency.

Keywords : Risk perception, Animal health, Plant health, Food safety, Online survey, Web survey

\section{Introduction}

The risk analysis paradigm consists of three distinct parts: risk assessment, risk management and risk communication (Regulation (EC) No 178/2002). Risk management in food safety is broadly separated in two complementary approaches: risk control and risk prevention (Regulation (EC) No 178/2002). In general, control measures are implemented once the hazard has occurred in the food chain, to decrease its adverse effects and/or severity, whereas 
prevention measures consist in avoiding the hazard occurring in the food chain, tackling problems at source, where possible.

Risk prevention is an integrated approach which is implemented throughout the whole food chain, at each and every production-processing-distribution stage (Regulation (EC) No 178/2002), involving all the stakeholders. Stakeholders are defined as any person, group or organization having an interest in or affected by the policy making (Regulation (EC) No 178/2002). Selection and implementation of risk prevention measures are not necessarily compulsory and can rely on the responsibility of each individual stakeholder. Therefore, the effective risk prevention throughout the food chain requires a strong active partnership between e.g. the producers, food business operators, veterinarians, transporters, retailers, consumers and public authorities. Understanding the process by which stakeholders decide to bring forward some preventive measures can help to build such a successful and sustainable commitment towards risk prevention. When considering the process by which stakeholders make decisions about risk prevention, it is especially important to identify the factors which drive and motivate their behaviour. In particular, stakeholders' concerns and perceptions can modify their decision-making process, influencing actual exposure indirectly. Effectively, the first-ever expected application of studying behaviour is changing stakeholders' behaviour, i.e. their practices. Communication is a valuable tool to promote positive risk prevention practices.

Understanding the common and different factors leading the decision-making process between stakeholders may guide improvement to risk communication. Development of a communication approach about risk prevention in the food chain can be conducted either at a global level, or targeted and stakeholder- or field of competency-tailored if significant differences are observed. Identification of the related factors is critical in understanding the decision-making process and needs an integrated multidisciplinary approach, including social sciences (Mills et al., 2011).

The human behavioural science and theory, i.e. studying the process from social construction of subjective judgments to rational decision making, is often referred to as social epidemiology when applied on populations. It is well known that many factors influence people's risk perception (Botterill \& Mazur, 2004). Consequently, there is likely to be a substantial variation amongst stakeholders with respect to what represents an acceptable/tolerable level of risk. Levels of acceptable/tolerable risk are value-based and affected by many factors. As well as the obvious elements of benefits and costs, these factors also comprise culture and perception of the risk, which are themselves influenced by many further factors.

These notably include voluntariness, controllability, delay effect, natural versus manmade, familiarity and habituation, benefit and risk-benefit distribution, and the role of the media (Schmidt, 2004). What is considered to be an acceptable/tolerable level of risk will therefore vary depending upon which group of stakeholders is being considered. Thus, risk perception may lead to distortions of risk prevention priorities among the stakeholders (Ilbery, Maye, Ingram, \& Little, 2013; Kristensen \& Jakobsen, 2011; Simon-Grifé et al., 2013).

Only few studies on stakeholders' opinions to food safety are available (Sargeant et al., 2007; Van Boxstael et al., 2013; van Kleef et al., 2006), and they are mainly focused on risk control measures or policy (Sargeant et al., 2007; van Kleef et al., 2006). Studies on attitudes towards risk prevention have mainly concerned the adoption of biosecurity practices by farmers in animal productions (Barnes, Moxey, Ahmadi, \& Borthwick, 2015; Brennan \& Christley, 2013; Gunn, Heffernan, Hall, McLeod, \& Hovi, 2008; Racicot, Venne, Durivage, \& Vaillancourt, 2012; Simon-Grifé et al., 2013), whereas, to date, studies on attitudes towards risk prevention in plant production have received less attention (Ilbery et al., 2013; Maye, Ilbery, \& Little, 2012). However, to the authors' knowledge, a survey on how risk prevention 
practices and their effectiveness are perceived by various stakeholders of the food chain in different fields of competency is lacking. Therefore, a specific survey was conducted to describe stakeholders' perceptions, attitudes and practices towards risk prevention in the food chain and to explore if common features could be extracted from different fields of competency or stakeholder groups in order to improve a future communication approach about risk prevention in the food chain.

\section{Materials and methods}

\subsection{Study design and sampling}

An online cross-sectional study was set up to investigate the similarities and differences between the perceptions, attitudes and practices of stakeholders towards risk prevention in different fields of competency in the food chain, e.g. food safety, animal health, plant health, public health and environment.

The study population consisted of different national and European stakeholders (as regards to the level of responsibilities) of the food chain who were invited to register to a national symposium organized by the Scientific Committee of the Belgian Federal Agency for the Safety of the Food Chain (FASFC) in 2014 on "Improving the safety of the food chain through risk prevention in plant and animal production" (Scientific Committee of the Belgian Federal Agency for the Safety of the Food Chain, 2014).

The survey was distributed in two ways. First, invitations requesting participation in the proposed online questionnaire was sent electronically to about 805 stakeholders at different national and European levels. Most of them were known professional contact points and had been involved in professional activities in the food chain. More than 200 of them had expressed an interest in risk prevention by their registration for the national symposium on risk prevention in the food chain. Second, the questionnaire was distributed through snowball sampling strategy, where the first wave of respondents distributed the questionnaire link to others via e-mail. This enabled to reach more people from a same stakeholder group within a same field of competency.

\subsection{Data collection}

Responses of the stakeholders were collected using an online anonymous questionnaire, created, hosted and shared using Google Drive ${ }^{\mathrm{TM}}$ (available upon request). Time required to respond to the questionnaire was approximately 10-15 min.

The questionnaire was divided into 4 sections: (1) personal information of the respondent (6 questions of which 2 were open-ended); (2) perceived main hazard and related risk factor in the food chain (3 questions, 2 open-ended); (3) attitudes towards risk prevention measures, i.e. 22 measures in the field of food safety, 25 in animal health and 16 in plant health, Appendix A (26, 29 and 20 questions, respectively, 1 open-ended); (4) measures implemented to prevent risk of the main hazard occurring or spreading (6 questions, 1 open-ended). In total, the questionnaire contained 44 questions (14\% open-ended and $86 \%$ closed) if respondent pertained to the field of animal health, 41 questions (15\% open-ended and $85 \%$ closed) for food safety and 35 questions (17\% open-ended and $83 \%$ closed) for plant health. No answer to the questionnaire was mandatory.

Questions for quantification of attitude towards risk prevention measures and the measures implemented were designed according to existing scientific literature, guidelines issued by the European measures. Respondents were asked to indicate how much they believe the proposed measures were useful or useless. Answers were measured on five-point Likert scales from "not useful at all” to "extremely useful” (28 questions for animal health, 25 questions for food 
safety and 19 questions for plant health). These enabled to differentiate not only between important and unimportant measures but also between positively and negatively rated measures. Respondents were classified as having a positive attitude if they believed the measure to be rather useful or a negative attitude if they considered the measure rather useless.

The questionnaire was reviewed by subject experts in the field of the food chain, including members of the Scientific Committee of the FASFC. A draft of the questionnaire was pretested to evaluate the interpretation of the questions, length of the questionnaire and easiness of the online system. Pre-testing was done with by 8 persons belonging to different groups of stakeholders and with different fields of competency.

The initial invitation to participate to the survey was sent on 15th October 2014. The survey was open for responses until 5th December 2014. Reminder e-mails were sent on 23rd October 2014 and 25th November 2014.

The survey was anonymous. It included neither personal nor sensitive data, and according to the European legislation, did not specifically require to be approved by an Ethical Committee.

\subsection{Data analysis}

Qualitative data extracted from the open questions (topics related to the perceived main hazard, associated risk factors and undertaken measures) were analysed using content analysis to identify thematic categories (Franzosi, 2004). An interpretative coding of the responses was used, which was driven by the data itself and not by pre-determined categories. Responses were then grouped together by thematic categories. Saturation was reached with no new issue raised and previously-raised issues being repeated. Any discrepancies in the coding were resolved by deliberation among the lead authors (CL and CS).

Each variable was described in terms of frequency distribution (qualitative data/thematic categories) or means and range (quantitative data).

The Chi2 test and Fisher's test (two sub-groups when the expected number of observations was less than 5), with $\alpha=0.05$, were applied to determine significant differences between the frequency distributions of variables between sub-groups (such as stakeholders or fields of competency).

The agreement between attitude, i.e. the perceived usefulness of proposed preventive measures, and behaviour, i.e. the actual measures undertaken, of the respondents towards risk prevention measures was assessed using concordance analysis. The level of agreement was expressed in terms of indices of positive and negative agreement (Cicchetti \& Feinstein, 1990), which are the observed agreement proportion for positive and negative measure scoring, respectively. The non-implementation of a measure was considered as a negative scoring. For the level of agreement, 95\% confidence interval was calculated according to the method of Graham \& Bull (1998). Response data gathered in Google Drive ${ }^{\mathrm{TM}}$ were exported into a Microsoft Excel spread sheet in a coded form with a time stamp key for anonymised identification of the respondents. Statistical analyses were conducted using Microsoft Excel (Microsoft Office

Excel, 2010) and R version 3.2.2 (the R Foundation for Statistical Computing, 2015).

\section{Results}

\subsection{Survey response}

The online survey response rate was $10 \%$, with 80 out of the 805 contacted food chain stakeholders. The profile of the respondents (if mentioned) was mainly decision maker (34), followed by scientist (29), sector representative (7), food business operator (5), consultants (3) 
and consumers (2) (Appendix B). The fields of competency were food safety (58), animal health (30), public health (28), plant health (17) and environment (2). On average, respondents had more than one field of competency (mean $=1.7$, range $=1-5$ ).

The average years of professional experience was 20 years (range $=1-50$ ) with little variation in years of experience between the fields of competency. Out of the 80 respondents, only 55 mentioned their country. They were mainly from Belgium (64\%) and France (15\%). Other countries are the Netherlands (5\%), Switzerland (4\%), Austria (1.7\%), Cyprus (1.7\%), Denmark (1.7\%), Finland (1.7\%), Romania (1.7\%), Slovenia (1.7\%) and United Kingdom $(1.7 \%)$.

\subsection{Perceptions}

In total, 73 respondents mentioned 54 different hazards, belonging to different thematic categories (Table 1). Pathogenic microorganisms were the main perceived hazard $(44 ; 60 \%)$ with different levels of specificity. For example, "food pathogens" [decision maker] or "new virus" [consultant] refer to generic pathogens, whereas Campylobacter spp. [consultant] or Drosophila suzukii [scientist] are much more specific. Distribution of the hazard categories did not differ between neither fields of competency nor stakeholders (Fisher test, $\mathrm{P}=0.72$ and $\mathrm{P}=0.90$, respectively).legislation and usual, mandatory or common risk prevention

Table 1 Quoted hazards by field of competencya and group of stakeholders ( $\mathrm{N}=73)$, online survey conducted during the 2014 Belgian FASFC symposium.

a One respondent could have more than one field of competency.

b One respondent quoted two hazards.

Eighteen of the 76 respondents (24\%) believed that climate change was the main risk factor related to the main hazard quoted (Table 2). Globalization (13; 17\%), lack of regulation (12; $16 \%)$ and lack of hygiene (8; 11\%) were the main other quoted drivers.

Fields of competency or stakeholder groups were not significantly associated with these perceptions ( $\mathrm{P}=0.93$ and $\mathrm{P}=0.45$, respectively).

Table 2 Perceived main risk factors by field of competency and group of stakeholders, online survey conducted during the 2014 Belgian FASFC symposium

Out of the 79 respondents, 58 (73\%) believed that the main hazard was preventable in the food chain, regardless of the field of competency or stakeholder group $(\mathrm{P}=0.73$ and $\mathrm{P}=0.23$, respectively) (Fig. 1a and $1 \mathrm{~b}$ ).

Figure 1. Perception, attitude and undertaken measures towards hazard/risk by field of competency and group of stakeholders

\subsection{Attitudes towards risk prevention}

Appendix A shows respondents' perceived usefulness about prevention measures for each field of competency. In the field of animal health, almost all the proposed risk prevention measures were perceived as useful, very useful or extremely useful.

Preventive drug treatment and selective breeding for disease resistance were the only two measures for which a negative attitude was observed. The majority of these perceptions did not vary between stakeholders, except for scientists believing on the usefulness disinfection between two successive batches compared to decision makers $(\mathrm{P}=0.040)$. In the field of plant health, the respondents showed a positive attitude towards the two thirds of the proposed risk prevention measures. In the field of food safety, the majority of the proposed risk prevention measures were perceived as useful, very useful or extremely useful. However, a higher 
proportion of respondents than in the other fields of competency believed that some of these measures were slightly useful or not useful at all. In particular, two risk prevention measures related to the increase of animal welfare were equally scored positively and negatively by the respondents. The majority of these perceptions did not differ between stakeholders. The exception was decision makers having more often than scientists a positive attitude towards post mortem inspection and a negative attitude towards increasing animal welfare during transport to slaughterhouse $(\mathrm{P}=0.058$ and $\mathrm{P}=0.027$, respectively). In all fields of competency, the respondents showed a positive attitude towards all the unspecific risk prevention measures related to communication, information, education programs etc. These perceptions did not differ between stakeholders within the fields of competency, except in food safety, where decision makers believed more often than scientists that increasing regulation is useless $(\mathrm{P}=0.046)$.

The 79 respondents believed that mainly competent authority (59; 75\%), food business operators $(49 ; 62 \%)$ and sector representatives $(43 ; 54 \%)$ should be responsible for the risk prevention. Other stakeholders were less cited, e.g. scientists $(17 ; 22 \%)$ or consumers $(2 ; 4 \%)$. This opinion did not varied between neither field of competency according to Chi2 test $(\mathrm{P}=$ 0.66) nor stakeholders $(\mathrm{P}=0.46)$.

Fifty nine of the 79 respondents (75\%) thought that the preventive measures should be mainly compulsory or all compulsory. This opinion was not different between neither stakeholders nor fields of competency ( $\mathrm{P}=0.59$ and $\mathrm{P}=0.84$, respectively) (Fig. $1 \mathrm{c}$ and $1 \mathrm{~d}$ ).

\subsection{Practices towards risk prevention}

Out of the 80 respondents, 60 (75\%) had already been confronted with the main hazard they mentioned in the questionnaire, for 27 of them (45\%) during the year of the survey, 40 of them (67\%) within the last 3 years before and 37 of them (62\%) more than 3 years before.

Out of these 60 respondents, 45 of them (75\%) had undertaken measures to prevent the mentioned hazard to occur or to spread. The main undertaken risk reduction measures were mainly regulatory but increased surveillance and communication actions were also often implemented (Table 3). Seventy-six percent of the undertaken measures were perceived as extremely or very useful whereas only $6 \%$ were believed to be not useful at all or slightly useful.

Table 3 Undertaken measures by field of competency, online survey conducted during the 2014 Belgian FASFC symposium

a e.g. import inspection, quarantine, tighter regulation.

b e.g. sector guide, training, information dissemination, recommendations.

c e.g. treatment of the product, destruction.

d e.g. risk assessment, dedicated survey.

e e.g. vaccination, temporary ban of animal movements.

f e.g. food chain information.

g e.g. cooperation with food business operators.

The main reasons to implement a risk prevention measure were policy obligation and public health concerns. The main reasons for inactivity were budgetary reasons and doubt on the effectiveness of the measures (Fig. 1e).

All these practices did not differ between fields of competency.

\subsection{Comparison between attitude and behaviour towards implementation of risk prevention measures}


In the field of food safety, the global agreement between the attitude and behaviour of the respondents towards useful risk prevention measures was estimated to be $50.0 \%$, 95\% CI [45.1-54.9], whereas the global negative agreement on useless measures was estimated to be 33.9\%, 95\% CI [27.4-40.5] (Table 4). In the field of animal health, the global positive agreement was estimated to be $48.9 \%, 95 \%$ CI [40.8-57.0], whereas the global negative agreement was estimated to be $36.0 \%$, 95\% CI [26.2-45.8]. In the field of plant health, the global positive agreement was estimated to be 32.6\%, 95\% CI [21.4-43.8], whereas the global negative agreement was estimated to be $8.8 \%$, 95\% CI [0-18.1].

Table 4 Comparison of attitude and behaviour towards implementation of risk prevention measure categories by field of competency.a

a Legend: The number of measures by category is in brackets with the following order (food safety; animal health; plant health): communication (4; 4; 4), surveillance $(2 ; 2 ; 2)$, regulation $(4 ; 2 ; 3)$ and biosecurity $(5 ; 9 ; 1)$.

\section{Discussion}

This study is one of the first to report on the stakeholders' perception, attitudes and practices in relation to the risk prevention in the food chain, including different fields of competency and stakeholder groups. A similar exercise was conducted focusing on the food safety field, with the aim to capture stakeholders' perceptions towards risk management at a whole (van Kleef et al., 2006). Animal-related studies on attitudes towards risk prevention have mainly concerned the farmscale biosecurity practices. To date, studies on attitudes towards risk prevention in plant production have received less attention.

As limitations, selection bias may have occurred because of the use of non-probabilistic sampling technique. Thus, the sample is mainly constituted by scientists and decision makers from the field of food safety. Nevertheless, a preanalysis was performed on 60 responses for the annual symposium of the Scientific Committee of the FASFC: the results obtained were consistent with those of the overall sample (data not shown). As saturation of responses (formally the point at which no new information or themes are observed in the data) was already reached with 60 respondents, we think this will not affect the internal validity of the results (Guest, Bunce, \& Johnson, 2006). The low response rate of the present survey is another limitation. However, web-based surveys often achieve lower response rates than other methods for data collection (Manfreda, Bosniak, Berzelak, Haas, \& Vehovar, 2008).

\subsection{Stakeholders' perceptions}

Regardless of their field of competency or group of stakeholders, a majority of respondents ( $\mathrm{N}$ $=44$ out of 73) believed that pathogenic microorganisms were the main potential hazard in the food chain. This is consistent with the results of previous studies regarding perceptions of food hazards, in which different groups of stakeholders agreed to consider bacterial pathogens as the main food safety issue for fresh produce, followed by foodborne viruses (Van Boxstael et al., 2013), or where microbiological contaminants were viewed as among the most serious hazards (Sparks \& Shepherd, 1994). Plant-related research has also reported plant diseases emerging as of primary concern for growers in the potato and wheat sectors (Ilbery et al., 2013).

One consistent observation from the present study was that stakeholders were homogeneous in their opinion, within and between the fields of competency. A previous study observed the experts as a more homogeneous group, this in contrast to consumers who were considered as a heterogeneous group (van Kleef et al., 2006). One explanation may be that our sample 
mainly consisted of experts from competent authority, industry or research institutes, whereas only two consumers took part of this study.

Seventy-three percent (58 out of 79) of the stakeholders believed that hazards in the food chain are preventable. The perceived controllability of risk is defined as the perceived control that people have over exposure to hazards (Botterill \& Mazur, 2004).

Assuming that risk perception is influenced notably by pre-existing knowledge (Scherr, Muller, \& Fast, 2013), the stakeholders' perception of their control in preventing a hazard to occur or to spread may be explained by the fact that our sample mainly consisted of experts. In contrast, this seems divergent with climate change as the main acknowledged risk factor for the potential hazards entering the food chain, for which people usually feel having little control over their own exposure.

To most stakeholders' opinion, the prevention measures should be compulsory and under the shared responsibility of food business operators and competent authority. This is partly consistent with the findings of a previous study, in which responsibility for food safety policy was attributed to all stakeholders along the food chain (Sargeant et al., 2007).

\subsection{Stakeholders' attitudes towards risk prevention}

A general positive attitude towards risk prevention measures was observed across all the fields of competency. The results of the present study are consistent with previous studies concerning different animal productions, in which most of the farmers were convinced of a positive effect of biosecurity on reduction of diseases at their farms (Brennan \& Christley, 2013; Laanen et al., 2014; Valeeva, van Asseldonk, \& Backus, 2011). In particular, according to Spanish pig farmers perceptions, the most important biosecurity practices were those aimed at minimizing the risk of disease introduction by visits and vehicles (Simon-Grifé et al., 2013). In this study, 65\% of the stakeholders having expertise in animal health showed a positive attitude towards such measures, but all-in-all-out management practices and cleaning and disinfection between successive batches were better rated. Conversely, a frequent negative attitude towards biosecurity was reported in UK cattle and sheep farmers (Gunn et al., 2008) and one study reported a negative attitude of Irish experts (veterinarians) towards on-farm usefulness biosecurity measures (Sayers, Good, \& Sayers, 2014). In the field of food safety, our results are also consistent with findings of previous studies in which positive attitude towards zoonotic programs and initiatives were reported in UK cattle farmers (EllisIversen et al., 2010) and Canadian dairy farmers (Young, Hendrick, et al., 2010).

\subsection{Implementation of risk prevention measures}

In the sample of the present study, most of the respondents had a recent experience of the quoted hazard and declared to have undertaken prevention measures. In animal productions, studies dealing with effective risk prevention have mainly investigated the implementation of biosecurity practices by farmers. Cattle and sheep farmers were reported to be generally dismissive of biosecurity (Gunn et al., 2008). Poor compliance with biosecurity measures at entrance or exit of poultry farms was also observed (Racicot et al., 2012). In plant production, although all farmers applied at least some measures to manage plant diseases, considerable difference among farmers was shown in the combination of measures undertaken (Breukers, van Asseldonk, Bremmer, \& Beekman, 2012).

Similarly as in animal productions, there is a general recognition that many farmers have not adopted decision support systems as part of their integrated pest management, notably to inform pesticide inputs (Way \& van Emden, 2000). 
This is also consistent with recurrent observation that previous experience is an incentive to undertake a risk prevention practice, such as biosecurity measures (Firestone et al., 2014; Garforth, Bailey, \& Tranter, 2013).

\subsection{Comparison between attitude and behaviour towards implementation of risk prevention measures}

In the present study, a discrepancy was observed between stakeholders' attitudes towards risk prevention and measures nominated as being undertaken. Some risk prevention practices could be perceived as useful but not undertaken, and conversely measures perceived as not useful being undertaken. Similar findings were observed in numbers of previous studies in which perceptions of prevention measures were not necessarily the same as the extent to which farmers actually use such measures (Brennan \& Christley, 2013; Carlier, Prou, Mille, \& Lupo, 2013; Ilbery, Maye, \& Little, 2012; Kristensen \& Jakobsen, 2011).

\subsection{Drivers of stakeholders' behaviour towards risk prevention}

In the present survey, the motivators to implement risk prevention measures were policy obligation and public health consequences whereas the main barriers were budgetary reasons and doubt on effectiveness of the measures. These findings are consistent with previous findings identifying high estimated costs (Breukers et al., 2012; Fraser, Williams, Powell, \& Cook, 2010; Simon-Grifé et al., 2013), belief in the efficacy of measures (Breukers et al., 2012; Garforth et al., 2013; Gunn et al., 2008), concern about public health issues (EllisIversen et al., 2010; Laanen et al., 2014), among other factors related to the implementation or non-implementation of risk prevention measures both in animal and plant productions. However, although mandatory aspects were quoted as an incentive in the present study, these did not seem to systematically improve the compliance of the farmers with the implementation of biosecurity measures (Fraser et al., 2010; Gunn et al., 2008; Kristensen \& Jakobsen, 2011; Laanen et al., 2014). As previously observed, risk prevention decisions seemed to be mainly framed in economic terms, with commercial interest over-riding disease (Carlier et al., 2013; Ilbery et al., 2013; Laanen et al., 2014; Wearing, 1988), welfare or environmental concerns. A recent review has illustrated the complexity of the effect of animal health compensation and penalties on preventative behaviours such as implementing biosecurity (Barnes et al., 2015).

Given that the research was exploratory in nature, we did not impose a theoretical model or framework on the data acquisition and analysis. The objective was to provide first insights into a relatively under-researched area. Different socio-psychological

frameworks have been used or adapted to investigate the decision-making process. They have been proven effective to explain or predict a large variety of behaviours (Armitage \& Conner, 2001), in both plant production, e.g. adoption of plant disease management practices (Breukers et al., 2012; McRoberts, Hall, Madden, \& Hughes, 2011), or animal production, e.g. implementation of biosecurity measures (Gunn et al., 2008; Valeeva et al., 2011) or zoonotic control programs (Ellis-Iversen et al., 2010). Therefore, the results of this study may be used to further develop a larger study to model the determinants of risk prevention commitment. This should further be used to promote and encourage the use of preventive measures by utilizing incentives or removing barriers for change.

\section{Conclusions and recommendations}

This study is one of the first to report on the stakeholders' perception, attitudes and practices towards risk prevention in the food chain, including different fields of competency and stakeholder groups. From these results it appears that homogeneous positive attitudes exist 
towards risk prevention in the food chain, regardless of stakeholder group or field of competency. This observation is important for improving the risk communication process because the same issues can be emphasized when promoting risk prevention regardless of the type of food sectors and stakeholder groups.

Such assessment should be conducted regularly to account for potential emerging issues and to ensure the acceptability, and commitment of the stakeholders with proposed risk prevention measures, and to improve their compliance, as a result. This may strengthen the link between the risk communication and the risk management processes, by helping to target the prevention measures to consider in determining plausible scenarios and to help to implement the best practices. Such regular surveys would also enable to assess the stability of the perceptions and attitudes over time and to adapt the risk communication strategy accordingly. These have important implications for formulating the proper recommendations to expand and preserve the sustainability of the food chain safety.

\section{Acknowledgement}

The authors greatly acknowledge all the respondents for their participation in the survey.

\section{Appendix A. Supplementary data}

Supplementary data related to this article can be found at http://dx.doi.org/10.1016/j.foodcont.2016.02.003 


\section{References}

Armitage, C. J., \& Conner, M. (2001). Efficacy of the theory of planned behaviour: a metaanalytic review. British Journal of Social Psychology, 40, 471e499. http://dx.doi.org/10.1348/014466601164939.

Barnes, A. P., Moxey, A. P., Ahmadi, B. V., \& Borthwick, F. A. (2015). The effect of animal health compensation on 'positive' behaviours towards exotic disease reporting and implementing biosecurity: a review, a synthesis and a research agenda. Preventive Veterinary Medicine, 122(1e2), 42e52. http://dx.doi.org/10.1016/j.prevetmed.2015.09.003.

Botterill, L., \& Mazur, N. (2004). Risk and risk perception: A literature review (RIRDC Publication No 04/043). Retrieved from. Kingston, Australia: Rural Industries Research and Development Corporation https://rirdc.infoservices.com.au/items/04-043.

Brennan, M. L., \& Christley, R. M. (2013). Cattle producers' perceptions of biosecurity. BMC Veterinary Research, 9. http://dx.doi.org/10.1186/1746-6148-9-71.

Breukers, A., van Asseldonk, M., Bremmer, J., \& Beekman, V. (2012). Understanding growers' decisions to manage invasive pathogens at the farm level. Phytopathology, 102(6), 609e619. http://dx.doi.org/10.1094/Phyto-06-11-0178.

Carlier, M., Prou, J., Mille, D., \& Lupo, C. (2013). Oyster farmers' perception of spat mortality outbreaks: more a firm than a farm issue. In K. L. P. Verheyen, C. Fourichon, \& the SVEPM Executive Committee (Eds.), Proceedings of the Society for Veterinary Epidemiology and Preventive Medicine (pp. 226e237). Madrid, Spain: Society for Veterinary Epidemiology and Preventive Medicine.

Cicchetti, D. V., \& Feinstein, A. R. (1990). High agreement but low Kappa .2. Resolving the paradoxes. Journal of Clinical Epidemiology, 43(6), 551e558. http://dx.doi.org/10.1016/0895-4356(90)90159-M.

Ellis-Iversen, J., Cook, A. J. C., Watson, E., Nielen, M., Larkin, L., Wooldridge, M., et al. (2010). Perceptions, circumstances and motivators that influence implementation of zoonotic control programs on cattle farms. Preventive Veterinary Medicine, 93(4), 276e285. http://dx.doi.org/10.1016/j.prevetmed.2009.11.005.

Firestone, S. M., Lewis, F. I., Schemann, K., Ward, M. P., Toribio, J. A. L. M. L., Taylor, M. R., et al. (2014). Applying Bayesian network modelling to understand the links between on-farm biosecurity practice during the 2007 equine influenza outbreak and horse managers' perceptions of a subsequent outbreak. Preventive Veterinary Medicine, 116(3), 243e251. http://dx.doi.org/10.1016/j.prevetmed.2013.11.015.

Franzosi, R. (2004). Content analysis. In M. Hardy, \& A. Bryman (Eds.), Handbook of data analysis (pp. 548e566). London, England: SAGE Publications, Ltd.

Fraser, R. W., Williams, N. T., Powell, L. F., \& Cook, A. J. C. (2010). Reducing Campylobacter and Salmonella infection: two studies of the economic cost and attitude to adoption of on-farm biosecurity measures. Zoonoses and Public Health, 57(7e8), E109eE115. http://dx.doi.org/10.1111/j.1863-2378.2009.01295.x.

Garforth, C. J., Bailey, A. P., \& Tranter, R. B. (2013). Farmers' attitudes to disease risk management in England: a comparative analysis of sheep and pig farmers. Preventive Veterinary Medicine, 110(3e4), 456e466. http://dx.doi.org/10.1016/j.prevetmed.2013.02.018.

Graham, P., \& Bull, B. (1998). Approximate standard errors and confidence intervals for indices of positive and negative agreement. Journal of Clinical Epidemiology, 51(9), 763e771. http://dx.doi.org/10.1016/S0895-4356(98)00048-1.

Guest, G., Bunce, A., \& Johnson, L. (2006). How many interviews are enough? An experiment with data saturation and variability. Field Methods, 18(1), 59e82. http://dx.doi.org/10.1177/1525822X05279903. 
Gunn, G. J., Heffernan, C., Hall, M., McLeod, A., \& Hovi, M. (2008). Measuring and comparing constraints to improved biosecurity amongst GB farmers, veterinarians and the auxiliary industries. Preventive Veterinary Medicine, 84(3e4), 310e323. http://dx.doi.org/10.1016/j.prevetmed.2007.12.003.

Ilbery, B., Maye, D., Ingram, J., \& Little, R. (2013). Risk perception, crop protection and plant disease in the UK wheat sector. Geoforum, 50, $129 \mathrm{e} 137$. http://dx.doi.org/10.1016/j.geoforum.2013.09.004.

Ilbery, B., Maye, D., \& Little, R. (2012). Plant disease risk and grower-agronomist perceptions and relationships: an analysis of the UK potato and wheat sectors. Applied Geography, 34, 306e315. http://dx.doi.org/10.1016/j.apgeog.2011.12.003.

van Kleef, E., Frewer, L. J., Chryssochoidis, G. M., Houghton, J. R., Korzen-Bohr, S., Krystallis, T., et al. (2006). Perceptions of food risk management among key stakeholders: results from a cross-European study. Appetite, 47(1), $46 \mathrm{e} 63$. http://dx.doi.org/10.1016/j.appet.2006.02.002.

Kristensen, E., \& Jakobsen, E. B. (2011). Danish dairy farmers' perception of biosecurity. Preventive Veterinary Medicine, 99(2e4), 122e129. http://dx.doi.org/10.1016/j.prevetmed.2011.01.010

Laanen, M., Maes, D., Hendriksen, C., Gelaude, P., De Vliegher, S., Rosseel, Y., et al. (2014). Pig, cattle and poultry farmers with a known interest in research have comparable perspectives on disease prevention and on-farm biosecurity. Preventive Veterinary Medicine, 115(1e2), 1e9. http://dx.doi.org/10.1016/j.prevetmed.2014.03.015.

Manfreda, K. L., Bosniak, M., Berzelak, J., Haas, I., \& Vehovar, V. (2008). Web surveys versus other survey modes e a meta-analysis comparing response rates. International Journal of Market Research, 50(1), 79e104.

Maye, D., Ilbery, B., \& Little, R. (2012). Rationalising risk: grower strategies to manage plant disease in the UK wheat and potato sectors. Geographical Journal, 178, 338e347. http://dx.doi.org/10.1111/j.1475-4959.2012.00485.x.

McRoberts, N., Hall, C., Madden, L. V., \& Hughes, G. (2011). Perceptions of disease risk: from social construction of subjective judgments to rational decision making. Phytopathology, 101(6), 654e665. http://dx.doi.org/10.1094/Phyto-04-10-0126.

Mills, P., Dehnen-Schmutz, K., Ilbery, B., Jeger, M., Jones, G., Little, R., et al. (2011). Integrating natural and social science perspectives on plant disease risk, management and policy formulation. Philosophical Transactions of the Royal Society B-Biological Sciences, 366(1573), 2035e2044. http://dx.doi.org/10.1098/rstb.2010.0411.

Racicot, M., Venne, D., Durivage, A., \& Vaillancourt, J. P. (2012). Evaluation of the relationship between personality traits, experience, education and biosecurity compliance on poultry farms in Quebec, Canada. Preventive Veterinary Medicine, 103(2e3), 201e207. http://dx.doi.org/10.1016/j.prevetmed.2011.08.011.

Regulation (EC) No 178/2002 of the European Parliament and of the Council of 28 January 2002 laying down the general principles and requirements of food law, establishing the European Food Safety Authority and laying down procedures in matters of food safety. Official Journal of the European Union, L 031.

Sargeant, J. M., Ramsingh, B., Wilkins, A., Travis, R. G., Gavrus, D., \& Snelgrove, J. W. (2007). Constraints to microbial food safety policy: opinions from stakeholder groups along the farm to fork continuum. Zoonoses and Public Health, 54(5), 177e184. http://dx.doi.org/10.1111/j.1863-2378.2007.01042.x.

Sayers, R. G., Good, M., \& Sayers, G. P. (2014). A survey of biosecurity-related practices, opinions and communications across dairy farm veterinarians and advisors. Veterinary Journal, 200(2), 261e269. http://dx.doi.org/10.1016/j.tvjl.2014.02.010. 
Scherr, S., Muller, P., \& Fast, V. (2013). Do third-person perceptions amplify exemplification effects? International Journal of Communication, 7, 1603e1621. Retrieved from http://ijoc.org/index.php/ijoc/article/view/1725/1957.

Schmidt, M. (2004). Investigating risk perception: A short introduction. Chapter 3. Loss of agro-biodiversity in Vavilov centers, with a special focus on the risks of genetically modified organisms (GMOs) (Doctoral thesis). Austria: University of Vienna. Retrieved from http://www.markusschmidt.eu/pdf/Intro_risk_perception_Schmidt.pdf.

Scientific Committee of the Belgian Federal Agency for the Safety of the Food Chain. (2014). Improving the safety of the food chain through risk prevention in plant and animal production. Retrieved from http://www.favvafsca.fgov.be/wetenschappelijkcomite/workshops/_documents/FinalProgramSymposium2 014_EN.pdf.

Simon-Grif_e, M., Martin-Valls, G. E., Vilar-Ares, M. J., Garcia-Bocanegra, I., Martin, M., Mateu, E., et al. (2013). Biosecurity practices in Spanish pig herds: perceptions of farmers and veterinarians of the most important biosecurity measures. Preventive Veterinary Medicine, 110(2), 223e231. http://dx.doi.org/10.1016/j.prevetmed.2012.11.028.

Sparks, P., \& Shepherd, R. (1994). Public perceptions of the potential hazards associated with food-production and food-consumption e an empirical-study. Risk Analysis, 14(5), 799e806. http://dx.doi.org/10.1111/j.1539-6924.1994.tb00291.x.

Valeeva, N. I., van Asseldonk, M. A. P. M., \& Backus, G. B. C. (2011). Perceived risk and strategy efficacy as motivators of risk management strategy adoption to prevent animal diseases in pig farming. Preventive Veterinary Medicine, 102(4), 284e295. http://dx.doi.org/10.1016/j.prevetmed.2011.08.005.

Van Boxstael, S., Habib, I., Jacxsens, L., De Vocht, M., Baert, L., Van de Perre, E., et al. (2013). Food safety issues in fresh produce: bacterial pathogens, viruses and pesticide residues indicated as major concerns by stakeholders in the fresh produce chain. Food Control, 32(1), 190e197. http://dx.doi.org/10.1016/j.foodcont.2012.11.038.

Way, M. J., \& van Emden, H. F. (2000). Integrated pest management in practice e pathways towards successful application. Crop Protection, 19(2), 81e103. http://dx.doi.org/10.1016/S0261-2194(99)00098-8.

Wearing, C. H. (1988). Evaluating the Ipm implementation process. Annual Review of Entomology, 33, 17e38. http://dx.doi.org/10.1146/annurev.en.33.010188.000313.

Young, I., Hendrick, S., Parker, S., Rajic, A., McClure, J. T., Sanchez, J., et al. (2010). Knowledge and attitudes towards food safety among Canadian dairy producers. Preventive Veterinary Medicine, 94(1e2), 65e76. http://dx.doi.org/10.1016/j.prevetmed.2009.11.010. 
Table 1. Quoted hazards by field of competency ${ }^{1}$ and group of stakeholders (N=73), online survey conducted during the 2014 Belgian FASFC symposium

\section{Hazard Field of \\ categorie competen}

\section{Group of stakeholders}

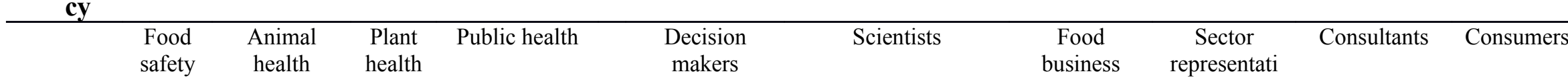

Microorganisms
Chemicals
(Myco)toxins
Climate change
Trade
Contaminants
Others

Total respondents

$\begin{array}{cccc}30 & 19 & 10 & 17 \\ 6 & 3 & 1 & 4 \\ 5 & 0 & 1 & 1 \\ 0 & 1 & 0 & 1 \\ 1 & 1 & 4 & 0 \\ 2 & 2 & 0 & 1 \\ 8 & 2 & 0 & 2 \\ \mathbf{5 2} & \mathbf{2 7}^{2} & \mathbf{1 6} & \mathbf{2 5}^{\mathbf{2}}\end{array}$

\begin{tabular}{cccccc}
\multicolumn{7}{c}{ operators } & ves & & \\
\hline 18 & 15 & 2 & 4 & 3 & 1 \\
4 & 3 & 0 & 0 & 0 & 0 \\
2 & 2 & 0 & 1 & 0 & 0 \\
0 & 2 & 0 & 0 & 0 & 0 \\
4 & 2 & 0 & 0 & 0 & 0 \\
1 & 1 & 1 & 0 & 0 & 0 \\
3 & 2 & 1 & 1 & 0 & 0 \\
\hline $\mathbf{3 1}^{\mathbf{1}}$ & $\mathbf{2 7}$ & $\mathbf{4}$ & $\mathbf{6}$ & $\mathbf{3}$ & $\mathbf{1}$
\end{tabular}

1 One respondent could have more than one field of competency.

2 One respondent quoted two hazards. 
Table 2. Perceived main risk factors by field of competency and group of stakeholders, online survey conducted during the 2014 Belgian FASFC symposium

\begin{tabular}{|c|c|c|c|c|c|c|c|c|c|c|c|}
\hline \multirow{2}{*}{$\begin{array}{l}\text { Risk } \\
\text { factor } \\
\text { categori } \\
\text { es }\end{array}$} & \multirow{2}{*}{$\begin{array}{c}\text { Total } \\
\text { respond } \\
\text { ents } \\
\left(\mathrm{N}=76^{3}\right)\end{array}$} & $\begin{array}{l}\text { Field of } \\
\text { compete } \\
\text { ncy }\end{array}$ & \multicolumn{9}{|c|}{ Group of stakeholders } \\
\hline & & $\begin{array}{c}\text { Food safety } \\
\left(\mathrm{N}=54^{3}\right)\end{array}$ & $\begin{array}{c}\text { Animal } \\
\text { health } \\
(\mathrm{N}=29)\end{array}$ & $\begin{array}{c}\text { Plant } \\
\text { health } \\
\left(\mathrm{N}=17^{3}\right)\end{array}$ & $\begin{array}{c}\text { Public } \\
\text { health } \\
\left(\mathrm{N}=25^{3}\right)\end{array}$ & $\begin{array}{c}\text { Decision } \\
\text { makers } \\
\left(\mathrm{N}=34^{3}\right)\end{array}$ & $\begin{array}{c}\text { Scientists } \\
(\mathrm{N}=27)\end{array}$ & $\begin{array}{c}\text { Food } \\
\text { business } \\
\text { operators } \\
(\mathrm{N}=5) \\
\end{array}$ & $\begin{array}{c}\text { Sector } \\
\text { representat } \\
\text { ives } \\
(\mathrm{N}=7) \\
\end{array}$ & $\begin{array}{c}\text { Consultant } \\
\mathrm{s} \\
(\mathrm{N}=3)\end{array}$ & $\begin{array}{c}\text { Consumers } \\
(\mathrm{N}=1)\end{array}$ \\
\hline $\begin{array}{l}\text { Climate } \\
\text { change }\end{array}$ & 18 & 14 & 6 & 5 & 4 & 5 & 8 & 2 & 1 & 1 & 0 \\
\hline $\begin{array}{l}\text { Global } \\
\text { trade }\end{array}$ & 13 & 8 & 5 & 3 & 5 & 8 & 5 & 0 & 0 & 0 & 0 \\
\hline $\begin{array}{l}\text { Lack of } \\
\text { regulatio } \\
n\end{array}$ & 12 & 6 & 5 & 3 & 2 & 5 & 5 & 0 & 1 & 0 & 0 \\
\hline $\begin{array}{l}\text { Lack of } \\
\text { hygiene }\end{array}$ & 8 & 7 & 2 & 2 & 3 & 5 & 1 & 0 & 2 & 0 & 1 \\
\hline $\begin{array}{l}\text { Inapprop } \\
\text { riate } \\
\text { producti } \\
\text { on } \\
\text { practices }\end{array}$ & 6 & 6 & 1 & 0 & 0 & 2 & 2 & 2 & 0 & 0 & 0 \\
\hline $\begin{array}{l}\text { Lack of } \\
\text { communi } \\
\text { cation }\end{array}$ & 3 & 3 & 0 & 0 & 1 & 1 & 2 & 0 & 0 & 0 & 0 \\
\hline $\begin{array}{l}\text { Environ } \\
\text { mental } \\
\text { pollution } \\
\text { s }\end{array}$ & 3 & 3 & 0 & 0 & 2 & 2 & 1 & 0 & 0 & 0 & 0 \\
\hline $\begin{array}{l}\text { Economi } \\
\text { c issues }\end{array}$ & 2 & 2 & 1 & 0 & 1 & 2 & 0 & 0 & 0 & 0 & 0 \\
\hline Others & 15 & 9 & 9 & 5 & 9 & 7 & 5 & 3 & 3 & 2 & 0 \\
\hline
\end{tabular}


Table 3. Undertaken measures by field of competency, online survey conducted during the 2014 Belgian FASFC symposium

\begin{tabular}{|c|c|c|c|c|c|}
\hline Measure categories & Total & Food safety & $\begin{array}{c}\text { Animal } \\
\text { health }\end{array}$ & Plant health & Public health \\
\hline Regulation $^{3}$ & 27 & 19 & 5 & 7 & 5 \\
\hline Communication $^{4}$ & 16 & 14 & 4 & 2 & 4 \\
\hline Surveillance & 15 & 11 & 7 & 5 & 7 \\
\hline Curative measures $^{5}$ & 6 & 1 & 2 & 4 & 2 \\
\hline Hygiene and biosecurity & 8 & 8 & 4 & 0 & 4 \\
\hline Knowledge acquisition $^{6}$ & 8 & 7 & 1 & 1 & 1 \\
\hline Specific prevention measures ${ }^{7}$ & 5 & 4 & 4 & 0 & 4 \\
\hline Traceability $^{8}$ & 2 & 2 & 1 & 0 & 1 \\
\hline Others $^{9}$ & 5 & 5 & 0 & 2 & 0 \\
\hline Total respondents & 45 & 32 & 13 & 9 & 13 \\
\hline
\end{tabular}

3 e.g. import inspection, quarantine, tighter regulation

4 e.g. sector guide, training, information dissemination, recommendations

5 e.g. treatment of the product, destruction

6 e.g. risk assessment, dedicated survey

7 e.g. vaccination, temporary ban of animal movements

8 e.g. food chain information

9 e.g. cooperation with food business operators 
Table 4. Comparison of attitude and behaviour towards implementation of risk prevention measure categories by field of competency ${ }^{10}$

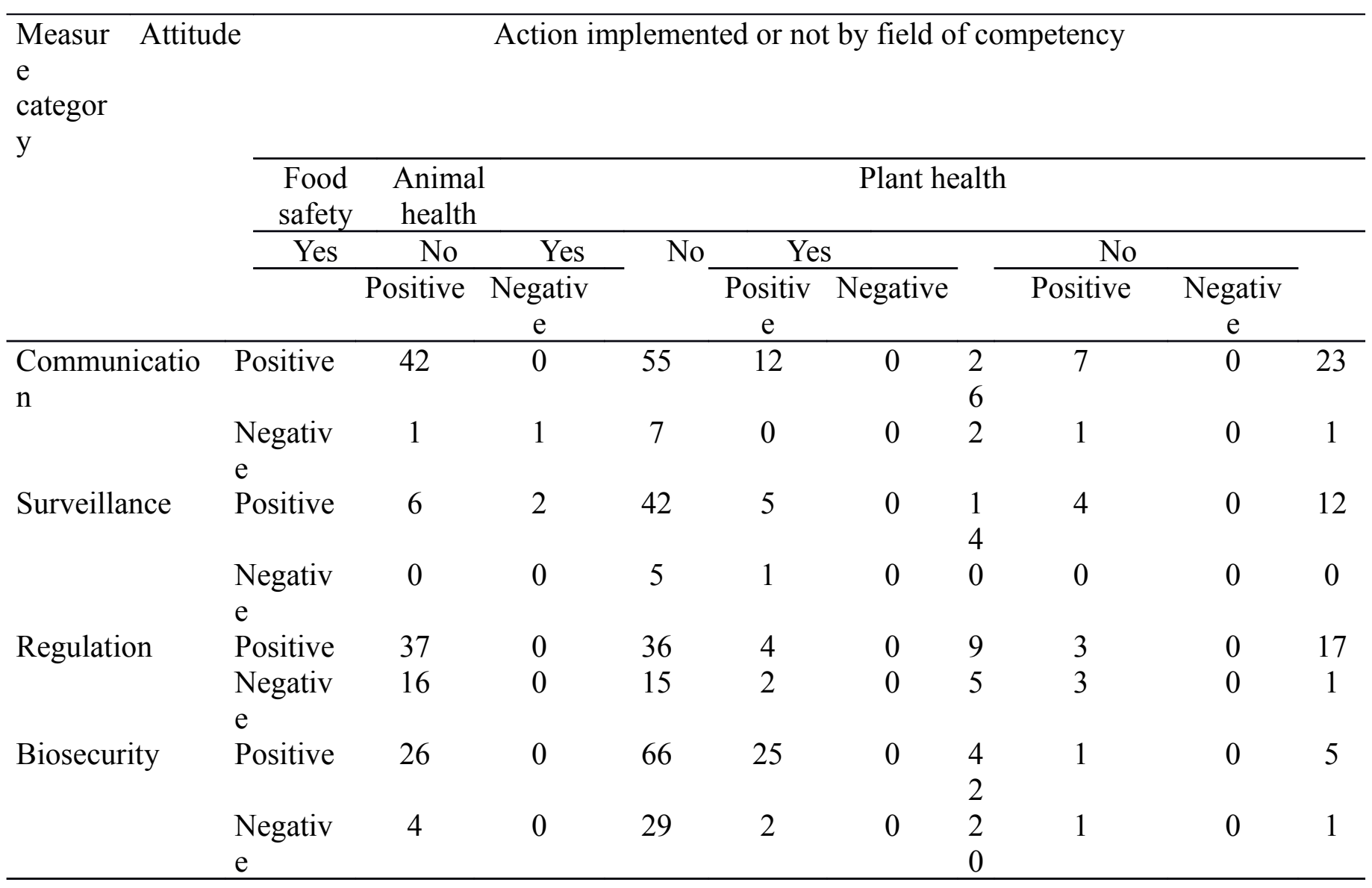

10 Legend: The number of measures by category is in brackets with the following order (food safety; animal health; plant health): communication ( $4 ; 4 ; 4)$, surveillance $(2 ; 2 ; 2)$, regulation $(4 ; 2 ; 3)$ and biosecurity $(5 ; 9 ; 1)$. 
Figure 1. Perception, attitude and undertaken measures towards hazard/risk by field of competency and group of stakeholders

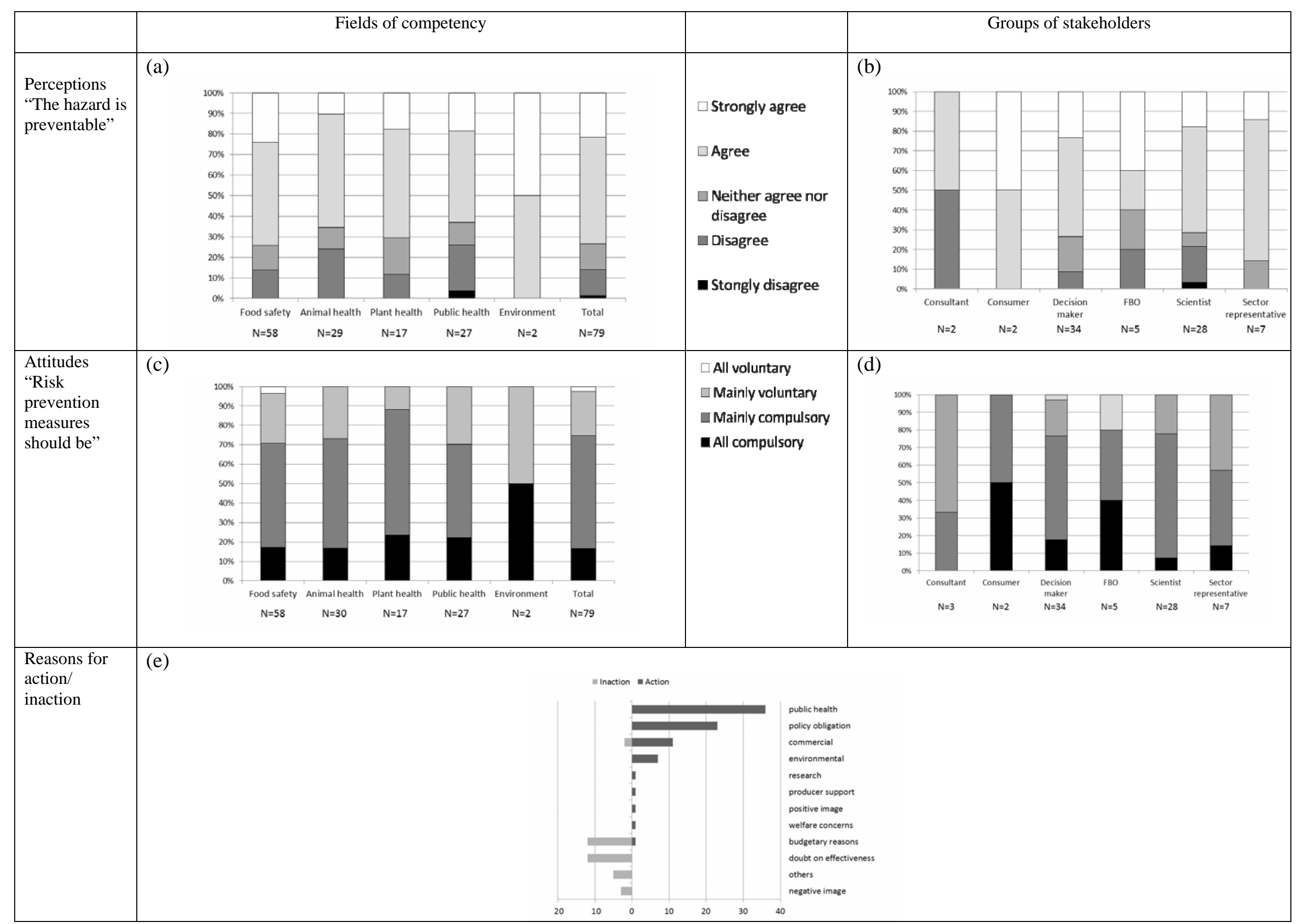

